\title{
Study of Pre-Monsoon Thunderstorms and Associated Thermodynamic Features Over Bangladesh Using WRF-ARW Model
}

\author{
Pappu Paul, Ashik Imran, Md. Jafrul Islam, Alamgir Kabir, Sahadat Jaman, and Ishtiaque M. Syed \\ ${ }^{2}$ Department of Physics, Dhaka University, Dhaka-1000, Bangladesh
}

(Received : 23 May 2019 ; Accepted: 21 July 2019 )

\begin{abstract}
Thunderstorm is a mesoscale system (from a $\mathrm{km}$ to below thousands of $\mathrm{km}$ and sustaining less than one hour). Two premonsoon thunderstorms events are analyzed in this study which are named as event-1 (0030-0150 UTC of 19 April 2018 over Chattogram) and event-2 (0600-1000 UTC of 4 May 2018 over Dhaka). To predict these events Mean Convective Available Potential Energy (mCAPE), Mean Convective Inhibition Energy (mCINE), K Index (KI), Total totals Index (TTI), wind distribution, and relative humidity $(\mathrm{RH})$ are investigated.The model simulated mCAPE and mCINE values, 18 hours before the events, are found greater than $1700 \mathrm{~J} / \mathrm{Kg}$ and less than $100 \mathrm{~J} / \mathrm{Kg}$ respectively which satisfies the conditions for thunderstorms to occur. The KI values are close to $40^{\circ} \mathrm{C}$ and TTI values are greater or equal to $45^{\circ} \mathrm{C}$ for both events. The wind patterns and the high value of mid -tropospheric RH also favors the formation of severe thunderstorm.
\end{abstract}

Keywords: Thunderstorm, mCAPE, mCINE, KI, TTI, RH.

\section{Introduction}

Thunderstorms are the local severe storms which cause huge loss of lives and damage to properties. Thunderstorms consist of three stages of evolution, namely, cumulus stage (updraft), mature stage (updraft and downdraft), and dissipating stage (downdraft) ${ }^{1}$. They are classified as single cell, multicell, squall line and supercell ${ }^{2}$. Thunderstorms cause heavy rain, lightning, hail, thunder, gusty wind squalls $^{3}$. Prediction of these events using weather prediction models is still difficult because of relative coarse resolution, lack of observations of the initial state, and the limited predictability of small mesoscale phenomena ${ }^{4}$. Meteorologists use stability indices to quickly asses the occurrence of the thunderstorms. These indices are a measure of the atmospheric stationary stability ${ }^{5}$. Yamane et al. ${ }^{6}$ demonstrated that Convective Available Potential Energy (CAPE) represents the atmospheric instability required for the formation of severe local storms over the Indian subcontinent. Kunz ${ }^{7}$ examined the skill of convective parameters and indices to predict isolated and severe thunderstorms over south-west Germany. Litta and Mohanty ${ }^{8}$ have used the thermodynamic indices values specified in the literature to identify the occurrence of thunderstorm activity in their modelling study of a thunderstorm event. In this study, we have selected two thunderstorm events, namely, event-1 (0030-0150 UTC of 19 April 2018 over Chattogram) and event-2 (0600-1000 UTC of 4 May 2018 over Dhaka) and used WRF model to investigate various parameters.

\section{Model and Methodology}

\section{WRF Model Description ${ }^{9}$}

The Advanced Research Weather Research and Forecast (ARW) version 3.8.1 mesoscale model developed by the National Center for Atmospheric Research (NCAR) is used in this study. The model is used for both research and operational forecasting and covers different meteorological phenomena. It includes multiple dynamical cores, a three- dimensional variational data assimilation system and software architecture to allow computational parallelism and system extensibility ${ }^{10}$. The model includes fully compressible non-hydrostatic Euler equations and different prognostic variables that have conservation properties ${ }^{11}$. The terrain following hydrostatic pressure is considered as the vertical coordinate ${ }^{12}$. The equations also include the effects of moisture, Coriolis and curvature terms. The dynamics employed and domain configurations in the model for the present study are in Table 1 and Fig. 1.

Table 1. Overview of WRF model

\begin{tabular}{|c|c|}
\hline No. of domain & 1 \\
\hline Center of the domain & $23.42 \mathrm{~N}, 90.82 \mathrm{E}$ \\
\hline Resolution & 10 \\
\hline Vertical co-ordinate & 38 sigma levels \\
\hline No. of grid points & $\begin{array}{l}\text { West-east:120, South- } \\
\text { north:57 }\end{array}$ \\
\hline Horizontal grid system & Arakawa C-grid \\
\hline Time integration Scheme & $\begin{array}{l}3^{\text {rd }} \text { order Runge kutta } \\
\text { scheme }\end{array}$ \\
\hline Cumulus physics & Kain Fritsch \\
\hline Microphysics & Kessler Scheme \\
\hline $\begin{array}{l}\text { Planetary Boundary } \\
\text { scheme(PBL) scheme }\end{array}$ & Yonsei University \\
\hline Radiation & $\begin{array}{l}\text { Dudhia Shortwave Scheme } \\
\text { (short wave) } \\
\text { RRTM Longwave } \\
\text { Scheme(long wave) }\end{array}$ \\
\hline Run time(48 hour) & $\begin{array}{l}\text { Event-1:0000 UTC of } 17 \\
\text { April 2018 to 0000 of UTC } \\
19 \text { April } 2018 \\
\text { Event-2:0000 UTC of } 2 \\
\text { May 2018 to 0000 UTC of } \\
4 \text { May 2018 }\end{array}$ \\
\hline
\end{tabular}




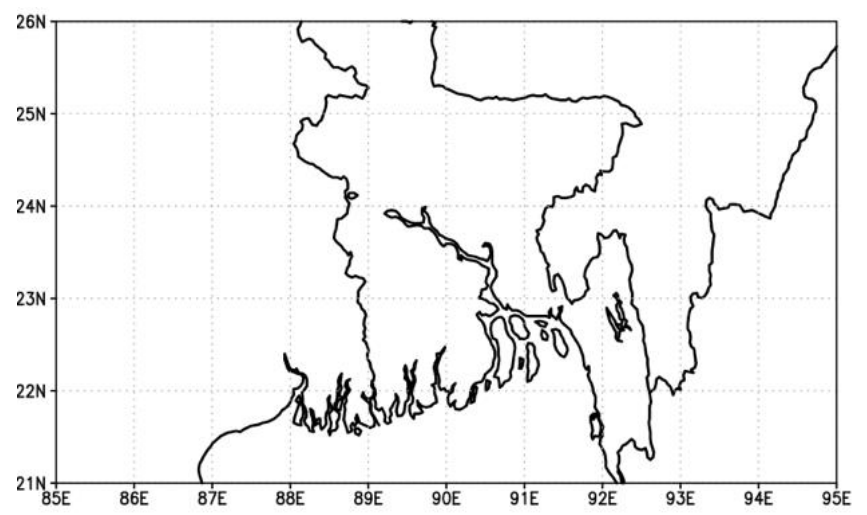

Fig. 1. WRF model domain configuration

\section{Methodology}

Model was run using six hourly NCEP (National Center for Environmental Prediction)-FNL datasets on $1^{\circ} \times 1^{\circ}$ grids. The model outputs help to investigate the synoptic and environmental characteristics for these events.

The Mean Convective Available Potential Energy $(\mathrm{mCAPE})^{13}$, Mean Convective Inhibition Energy $(\mathrm{mCINE})^{14}$, K-Index $(\mathrm{KI})^{15}$, Total totals Index $(\mathrm{TTI})^{16}$, wind speed, wind direction, relative humidity are investigated.

$$
C A P E(J / K g)=g \int_{z_{l f c}}^{z_{l n b}} \frac{T_{v e}-T_{v p}}{T_{v e}} d Z
$$

Where $g$ is the gravitational acceleration, $T_{v e}$ and $T_{v p}$ are the virtual temperatures of atmosphere and parcel respectively. $Z_{l n b}$ and $Z_{l f c}$ are the heights of the level of neutral buoyancy and the level of free convection respectively.

$$
\text { CINE }(J / K g)=g \int_{Z_{\text {ground }}}^{Z_{\text {top }}} \frac{T_{v p}-T_{v e}}{T_{v p}} d Z
$$

Where $Z_{\text {top }}$ is the level of free convection.

$$
K I\left({ }^{\circ} \mathrm{C}\right)=(T 850-T 500)+T d 850-(T 700-T d 700)
$$

According to Miller (1972) ${ }^{16}$

$$
\operatorname{TTI}\left({ }^{\circ} \mathrm{C}\right)=\mathrm{T} 850+\operatorname{Td} 850-2 T 500
$$

Where $T$ is the temperature and $T d$ is the dew point temperature at different pressure levels.The threshold values of different stability indices are in table 2 .

Table 2. Threshold value of stability indices ${ }^{17}$

\begin{tabular}{l|l}
\hline Stability indies & Threshold value \\
\hline CAPE & $>1500 \mathrm{~J} / \mathrm{Kg}$ \\
\hline CINE & $<200 \mathrm{~J} / \mathrm{Kg}$ \\
\hline KI & $>38^{\circ} \mathrm{C}$ \\
\hline TTI & $>45^{\circ} \mathrm{C}$ \\
\hline
\end{tabular}

\section{Result and Discussion}

Mean Convective Available Potential Energy (mCAPE) and Mean Convective Inhibition Energy (mCINE):
The spatial distribution of mCAPE (shaded) and mCINE (contour) for the event-1 is represented in Fig. 2. To predict this thunderstorm event, we have studied the outputs before 48 hours of the occurrence of the event. At 0300 UTC of 17 April 2018 (Fig. 2a), mCAPE and mCINE are found to be about $1400 \mathrm{~J} / \mathrm{Kg}$ and $50 \mathrm{~J} / \mathrm{Kg}$ respectively over the Chattogram region. Values of this parameter are found to be increasing with time and at 0900 UTC of 18 April 2018 mCAPE is around $1750 \mathrm{~J} / \mathrm{Kg}$ and mCINE is nearly 100 $\mathrm{J} / \mathrm{Kg}$. This increasing pattern of the values of mCAPE and mCINE are also found by Papa R. G. et al. ${ }^{17}$ The CAPE values i.e. the available buoyant energy for the vertical acceleration of the air parcels is found to be above 1500 $\mathrm{J} / \mathrm{Kg}$ for most of the time of the observation. Johns and Doswell (1992) ${ }^{18}$ suggested that values of CAPE above $1500 \mathrm{~J} / \mathrm{Kg}$ are favorable for the formation of supercells, which in turn, leads to the formation of thunderstorm events. At 0300 UTC of 17 April 2018 (Fig. 2a), values of $\mathrm{mCINE}$ are found to be above $200 \mathrm{~J} / \mathrm{Kg}$. Large values of mCINE is an indication of stable atmosphere and such atmospheric situation is not favorable for thunderstorm event even though the other factors are favorable for the occurrence of convective activities ${ }^{10}$. That is why no thunderstorm even is recorded by BMD over the southwestern part of Bangladesh. At 0900 UTC of 18 April (Fig. 2c) mCINE values are around $150 \mathrm{~J} / \mathrm{Kg}$. At $0000 \mathrm{UTC}$ of 19 April mCINE values are below $100 \mathrm{~J} / \mathrm{Kg}$ over most of the region of Bangladesh and values are extremely low (around $50 \mathrm{~J} / \mathrm{Kg}$ ) over the south eastern part of Bangladesh. The low value of mCINE along with the high value of mCAPE is clear indication for the formation of thunderstorm events over Chattogram and nearby territory.

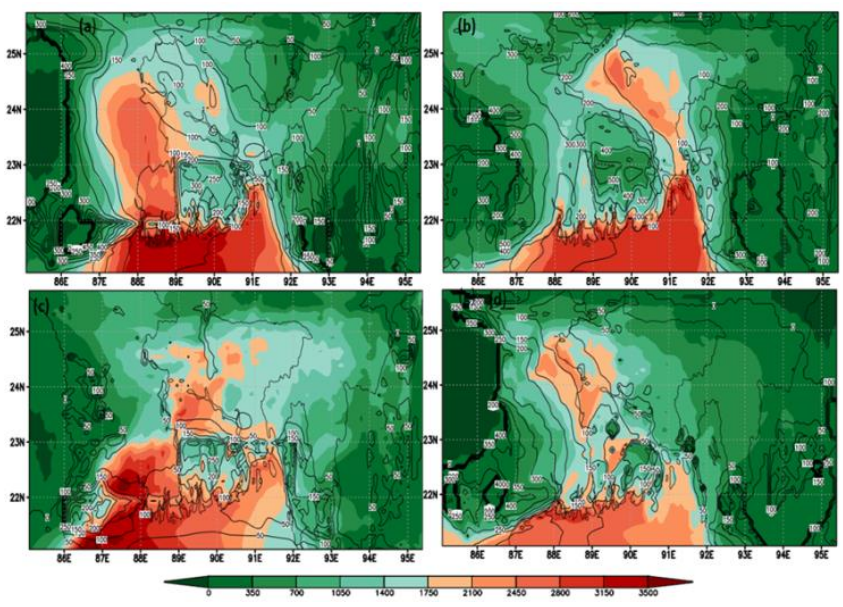

Fig. 2. mCAPE (J/Kg) (shaded) and mCINE (J/Kg)(contour) at (a)0300 UTC of 17 April, (b)1800 UTC of 17 April, (c)0900 UTC of 18 April, (d)0000 UTC of 19 April, 2018.

Fig. 3. mCAPE(shaded) and mCINE(contour) for the event2, starting form 0300 UTC of 2 May to 0900 UTC of 3 May, shows that the mCAPE values are around $2500 \mathrm{~J} / \mathrm{Kg}$. The mCINE values are very low (below $50 \mathrm{~J} / \mathrm{Kg}$ ) over the total observation period. Over the Dhaka region the mCINE values are below $30 \mathrm{~J} / \mathrm{Kg}$ and in some location these values are even low. These favorable atmospheric conditions lead 
to the formation of severe thunderstorm over Dhaka and its surrounding areas ${ }^{19}$.

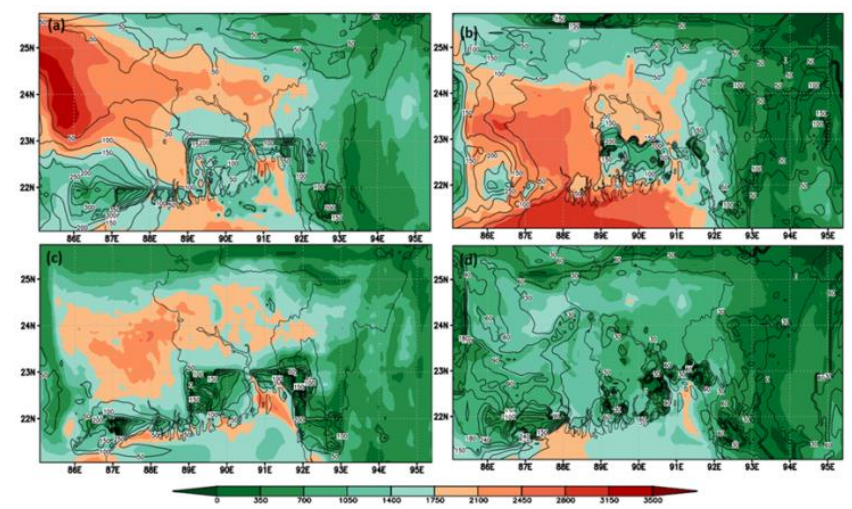

Fig. 3. $\mathrm{mCAPE}(\mathrm{J} / \mathrm{Kg})$ (shaded) and $\mathrm{mCINE}(\mathrm{J} / \mathrm{Kg})$ (contour) at (a) 0300 UTC of 2 May, (b) 1800 UTC of 2 May, (c) 0900 UTC of 3 May, (d) 0000 UTC of 4 May, 2018.

\section{K-Index(KI) and Total Totals Index (TTI):}

$K I$ values represent an aggregation of the Vertical Totals (VT) and lower atmosphere dew point temperature difference $^{20}$. Here, $V T$ is the lapse rate between $850 \mathrm{hPa}$ and $500 \mathrm{hPa}$. At $0300 \mathrm{UTC}$ of 17 April (Fig. 4a), KI is found to be approximately $35^{\circ} \mathrm{C}$ over the Chattogram. At 1800 UTC of 17 April (Fig. 4b), KI value is nearly $40^{\circ} \mathrm{c}$. These large values of $K I$ improve the probability of unstable weather ${ }^{17}$. At 0000 UTC of 19 April (Fig. 4d) the $K I$ values are close to $43^{\circ} \mathrm{C}$. As the $K I$ increases with time, so does the probability of having a severe thunderstorm ${ }^{16}$. The TTI values at 0300 UTC and at 1800 UTC of 17 April are approximately above $45^{\circ} \mathrm{C}$. At $0900 \mathrm{UTC}$ of 18 April the TTI values are even larger and reach above $50^{\circ} \mathrm{C}$. TTI values greater than $45^{\circ} \mathrm{C}$ is favorable for the development of thunderstorm ${ }^{18}$. At 0000UTC of 19 April, the TTI values are also very high, close to $50^{\circ} \mathrm{C}$. According to Haklander A.J. et al. ${ }^{21}$ TTI $\geq$ $46^{\circ} \mathrm{C}$ is favorable for severe thunderstorm. Therefore, the $K I$ and TTI values are always nearly equal or greater than threshold values which lead to the formation of thunderstorm (event-1).

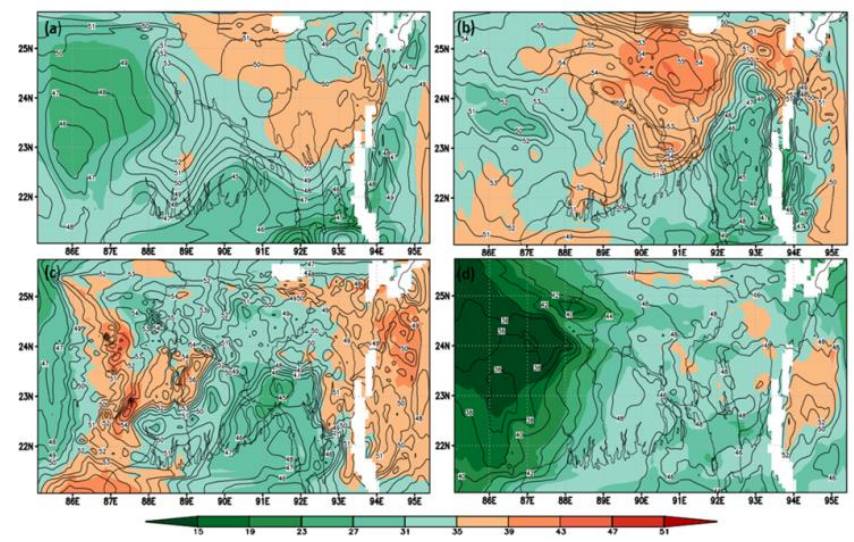

Fig. 4. $K I\left({ }^{\circ} \mathrm{C}\right)$ (shaded) and $T T I\left({ }^{\circ} \mathrm{C}\right)$ (contour) at (a)0300 UTC, (b)1800 UTC of 17 April, (c) 0900 UTC of 18 April, (d)0000 UTC of 19 April 2018.
Fig. 5 shows the same distribution but for event-2. Starting form $0300 \mathrm{UTC}$ to $1800 \mathrm{UTC}$ of 2 May, the $K I$ values are around $35^{\circ} \mathrm{C}$. The TTI values are very high (around $47^{\circ} \mathrm{C}$ ) over the total observation period. Throughout the Dhaka region the $K I$ values are greater than $40^{\circ} \mathrm{C}$ and in some location these values are even higher (close to $45^{\circ} \mathrm{C}$ ). These satisfactory thunderstorm conditions lead to the development of severe atmospheric situation over Dhaka and its adjacent areas ${ }^{19}$.

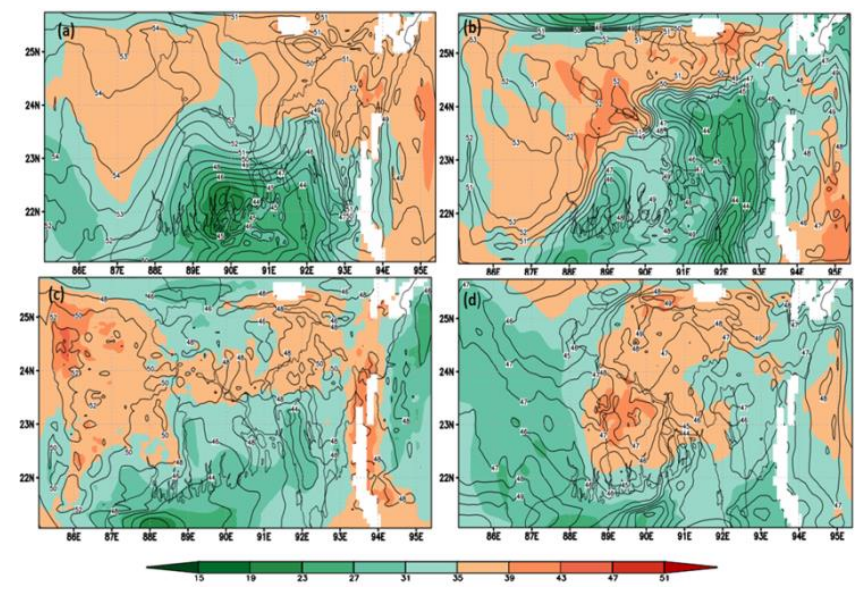

Fig. 5. $K I\left({ }^{\circ} \mathrm{C}\right)$ (shaded) and $\operatorname{TTI}\left({ }^{\circ} \mathrm{C}\right)$ (contour) at (a)0300 UTC of 2 May,(b) 1800 UTC of 2 May, (c) 0900 UTC of 3 May, (d)0000 UTC of 4 May 2018.

Distribution of Upper and Lower Level Wind:
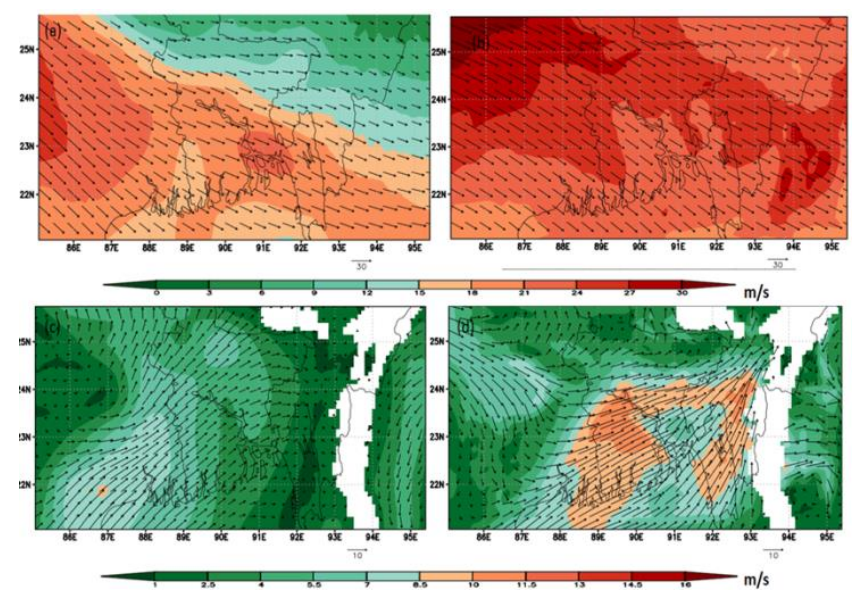

Fig. 6. Distribution of upper ( $350 \mathrm{hPa})$ and lower level $(900 \mathrm{hPa})$ wind (m/s), (a)0000 UTC of 17 April, (b)0000 UTC of 19 April in upper level, (c)0000 UTC of 17 April, (d)0000 UTC of 19 April 2018 in lower level.

Fig. 6 displays the wind speed $(\mathrm{m} / \mathrm{s})$ (shaded) and direction (arrow) for event-1.From the upper level of wind distribution at 0300 UTC of 17 April (Fig. 6a) and 0000 UTC of 19 April (Fig. 6b), wind speed is around $30 \mathrm{~m} / \mathrm{s}$ all over Bangladesh and winds are directed north easterly (dry air from the Himalayan region). This dry upper level air is one of the conditions that must be satisfied for the formation of thunderstorm ${ }^{10}$. 
On the other hand, the lower level wind (Fig. 6c) at 0300 UTC of 17 April, shows amaximum wind of $10 \mathrm{~m} / \mathrm{s}$ (much less than upper level wind speed). The south easterly wind direction confirms the arrival of wind from the Bay of Bengal (BoB) towards the Chattogram region. At 0000 UTC of 19 April (Fig. 6d), the lower level wind speed increases $(\sim 12 \mathrm{~m} / \mathrm{s})$. These airs from $\mathrm{BoB}$ enhance the moisture arrival and develop convective activities. These dry speedy air (heavy) in the upper level and moist air (lighter) in lower level is essential for thunderstorm occurrence which is also found by Ahsan et al. ${ }^{10}$
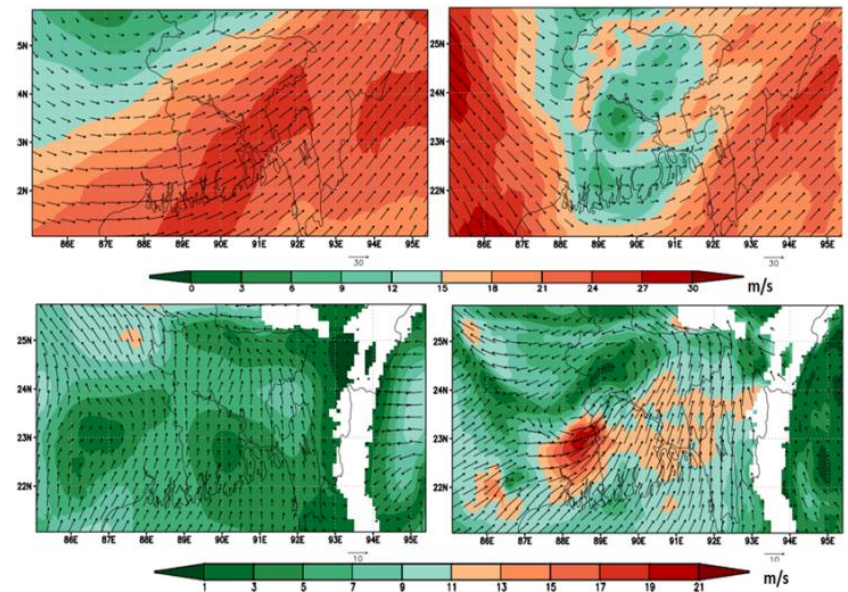

Fig. 7. Distribution of upper $(350 \mathrm{hPa})$ and lower level $(900 \mathrm{hPa})$ wind flow (m/s), (a) 0000 UTC of 2 May, (b) 0000 UTC of 4 May in upper level, (c) 0000 UTC of 2 May, (d)0000 UTC of 4 May 2018 in lower level.

Fig. 7(a-b) shows the distribution of upper level wind speed $(\mathrm{m} / \mathrm{s})$ and direction for the event-2. Circulating air from the Himalayan region with maximum speed $30 \mathrm{~m} / \mathrm{s}$ has flown over Dhaka. At 0000UTC of 2 May and 4 May (Fig. 7 c-d), wind (lower level) has come from ocean to land (southerly) with a speed of around $10 \mathrm{~m} / \mathrm{s}$, which shows the similar pattern like event-1.

So, in both events, the upper and lower level winds show the development of multi-cell thunderstorms. ${ }^{22}$

\section{Relative Humidity $(R H)$ :}

Fig. 8(a-d) shows the vertical profile of RH for event-1 along $91.5^{\circ} \mathrm{E}$ longitude (Chattogram). High $\mathrm{RH}$ of about70\% is found upto $400 \mathrm{hPa}$. High values of $\mathrm{RH}$ (moisture) between low and mid troposphere increase the probability of occurrence of thunderstorm ${ }^{23}$.

For event-2 (Fig. 9 (a-d)) the high RH distribution is more evident. At 0300 UTC of 2 May 2018, RH of the order of $90 \%$ is found only on the lower troposphere. RH increases with time $(\sim 100 \%)$ and extends upto top troposphere. At 0000 UTC of 4 May, the high intensity RH field has reached between 300 to $200 \mathrm{hPa}$. This updraft of moist air leads to the formation of thunderstorm over Dhaka region ${ }^{10}$.
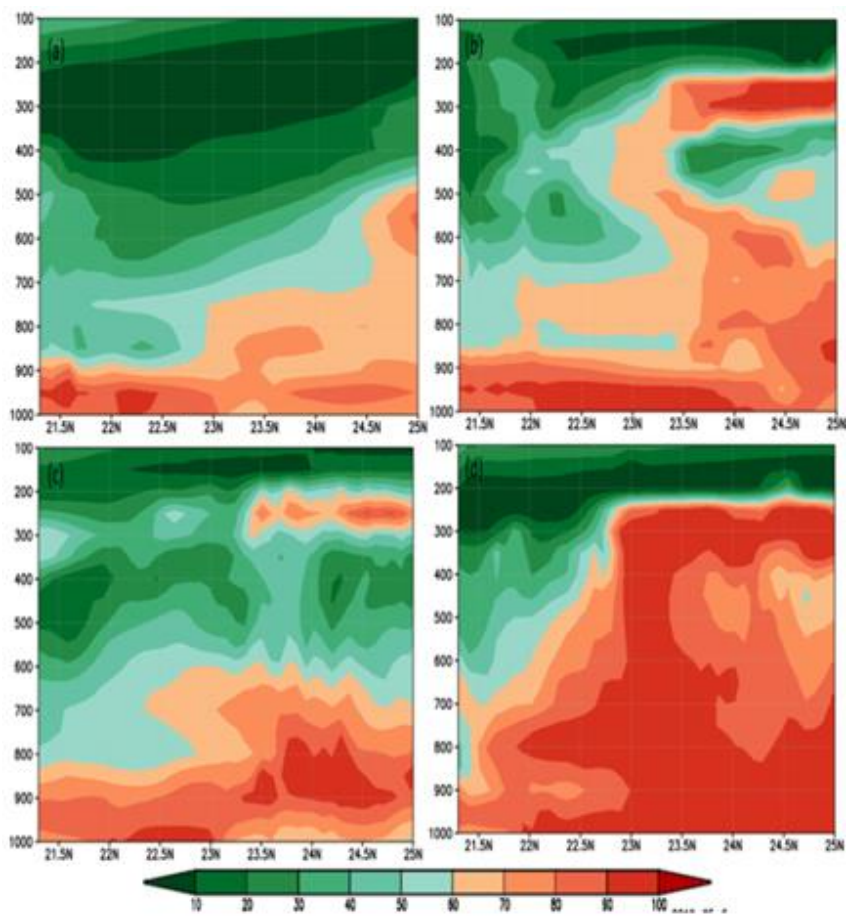

Fig. 8. Vertical profile of relative humidity along $91.5^{\circ} \mathrm{E}$ longitude (Chattogram) at (a) 0300 UTC, (b) 1800 UTC of 17 April 2018, (c) 0900 UTC of 18 April 2018, (d) 0000 UTC of 19 April 2018.
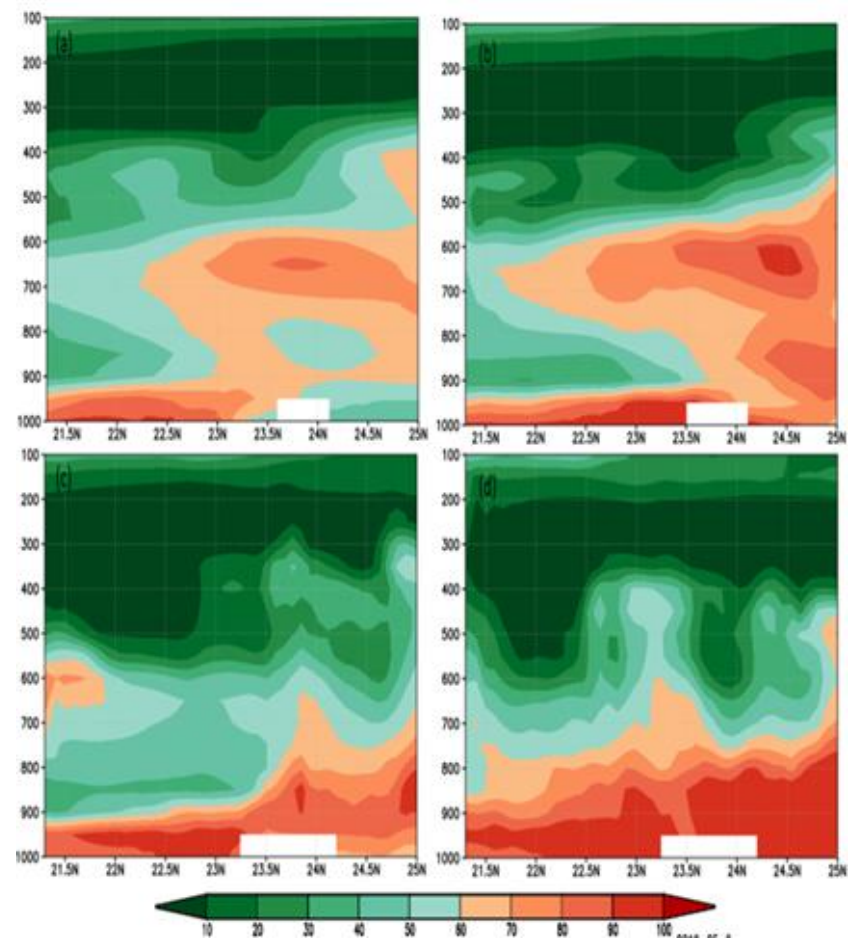

Fig. 9. Vertical profile of relative humidity along $90^{\circ} \mathrm{E}$ longitude (Dhaka) at (a) 0300 UTC, (b) 1800 UTC of 2 May 2018, (c) 0900 UTC of 3 May 2018, (d) 0000 UTC of 4May2018.

\section{Conclusion}

For predicting the thunderstorm events several stability indices (mCAPE, mCINE, KI, TTI), wind distribution, and 
RH are analyzed using WRF model. More than 18 hours before the event-1 the model simulated mCAPE and mCINE values are found greater than $1700 \mathrm{~J} / \mathrm{Kg}$ and less than $100 \mathrm{~J} / \mathrm{Kg}$ respectively and for event- 2 these values are found around $2500 \mathrm{~J} / \mathrm{Kg}$ and below $50 \mathrm{~J} / \mathrm{Kg}$ respectively. The KI and TTI values for event- 1 are found $43^{\circ} \mathrm{C}$ and $50^{\circ}$ $\mathrm{C}$ respectively and for event- 2 these values are found around $40^{\circ} \mathrm{C}$ and $45^{\circ} \mathrm{C}$ respectively, 18 hours before the event in both cases. The value of all these stability indices agrees with the threshold values stated in Table-2. The wind patterns and the high value of mid -tropospheric RH $(>70 \%)$ also favors the formation of severe thunderstorm. So, it can be concluded that the WRF-ARW model can predict the thunderstorm pretty well even 18 hours before the event. But for more accurate forecasting more studies with better resolutions are needed.

\section{References}

1. Rajeevan M., A. Kesarkar, S.B. Thampi, K.N. Rao, B. Radhakrishna and M. Rajsekhar, 2010. Sensitivity of WRF cloud microphysics to simulations of a severe thunderstorm event over Southeast India. Ann. Geophys., 28, 603-619.

2. Browning, K. A., 1986. General circulation of middle latitude thunderstorms; In: Thunderstorm morphology and dynamics; (ed.) Kessler E; Univ. Oklahoma Press, Norman, OK, 133152.

3. Brooks H. E. and R. B.Wilhelmson, 1992. Numerical simulation of a low-precipitation supercell thunderstorm, Meteorol Atmos Phys, 49, 3-17.

4. Tyagi B., V. N. Krishna and A. N. V. Satyanarayana, 2011. Study of Thermodynamic Indices in Forecasting PreMonsoon Thunderstorms over Kolkata during STORM Pilot Phase 2006-2008, Nat. Hazards, 56 (3), 681-698.

5. Peppier R.A., 1988. A review of static stability indices and related thermodynamic parameters. SWS Miscellaneous Publication, 104.

6. Yamane, Y. and T. Hayashi,2006. Evaluation of environmental conditions for the formation of severe local storms across the Indian subcontinent. Geophys. Res. Lett., 33, L17806.

7. Kunz M., 2007. The skill of convective parameters and indices to predict isolated and severe thunderstorms. Nat Hazards Earth Syst Sci, 7, 327-342.

8. Litta A.J., U.C. Mohanty, 2008. Simulation of a severe thunderstorm event during the field experiment of STORM programme 2006 using WRF-NMM model. Curr. Sci.,95(2), 204-215.
9. Skamarock W. C., J. B. Klwmp, J. Dudhia, D. O. Gill, D. M. Barker, M. G. Duda,X. Huang, W. Wang and J. G. Powers, 2008. A description of Advance Research WRF V3, NCAR Tech. Note NCAR/TN475+STR.

10. Ahasan M.N., S. K. Debsarma, 2015.Impact of data assimilation in simulation event over Bangladesh using WRF model, during SAARCSTORM Pilot Field Experiment 2011. Nat Hazards,75, 1009-1022.

11. Ooyama K. V., 1990. A thermodynamic formation for modeling the moist atmosphere,J. Atoms. Sci., 47, 2580-2593.

12. Laprise R., 1992. The Euler Equation of motion with hydrostatic pressure as independent variable, Mon. Wea. Rev., 120, 21-323

13. Moncrieff M, Miller M, 1976. The dynamics and simulation of tropical cumulonimbus and squall lines. $Q J R$ Meteorol Soc., 102, 373-394.

14. Colby, Jr. and P. Frank., 1984. Convective Inhibition as a Predictor of Convection during AVE-SESAME II. Mon. Wea. Rev.,112 (11), 2239-2252.

15. Galway J.G., 1956. The Lifted Index as a Predictor of Latent Instability, Bull. Am. Meteorol. Soc., 37, 528-529.

16. Miller R.C.,1972. Notes on analysis and severe storm forecasting procedures of the Air Force Global Weather Central. Tech. Rept. 200(R). Headquarters, Air Weather Service, USAF, 190.

17. Papa R. G., M. Rajasekhar, S. R. Pushpa, T. Sreeshna, M. Rajeevan and S.S.V.S. Ramakrishna, 2016. Prediction of severe thunderstorms over Sriharikota Island by usingthe WRF-ARW Operational Model.Proc. of SPIE, 9882, 988214-1.

18. Johns R H and C. A. Doswell, 1992. Severe local storms forecasting, Weather Forecast, 7,588-612.

19. Bangladesh Meteorological Department (BMD). http://www.bmd.gov.bd/

20. George J.J., 1960. Weather Forecasting for Aeronautics. New York City Academic Press. 673.

21. Haklander A.J., A.V. Delden, 2003. Thunderstorm predictors and their forecast skill for The Netherlands. Atmos. Res., 67, 273-299.

22. Holton J. R., An Introduction to DYNAMIC METEOROLOGY, Fourth edition, ELSEVIER ACADEMIC PRESS, 92.

23. Gibbs J.G.,A. Douglas and J.R. Butts, 2015.Warm-Season Thunderstorm Development as a Function of Vertical Distribution of Relative Humidity in the Lower Rio Grande Valley of Texas. J. Operational Meteor., 3(13), 145-155. 
